\title{
PROBLEMATIKA PENERAPAN PENDIDIKAN KARAKTER DI PONDOK PESANTREN KOTA PEKANBARU
}

\author{
Alfiah \\ Universitas Islam Negeri Sultan Syarif Kasim Riau, Indonesia \\ Email:alfiah@uin-suska.ac.id
}

\begin{abstract}
The implementation of character building at Islamic Boarding School in Pekanbaru; Darel Hikmah Islamic Boarding School, Babussalam Islamic Boarding School, and Al-Kautsar Modern Islamic Boarding School is proceeded through 3 integrated ways, namely; through the subject courses, through local contents, and through students' self development. Based on the preliminary study, writer found a discrepancy which indicates the implementation of character building in Islamic Boarding School Darel Hikmah, Babussalam and Al-Kautsar is not optimally applied. The discrepancy indicated that the character building in the schools does not have positive effect on students' characters; to adore God Al mighty and all His creature; respectful and well-mannered, generous, mutual cooperation, self-confidence and hardworker, leadership and equitable, humble, tolerance, peaceful and unity. The application of character building at these schools has been investigated through 26 indicators. The research shows that the indicators are in good level; 73.16\%. The first factor that support and barrier the application of character building in these Islamic Boarding Schools is funding; there is no specific fund to support the education character building implementation. The second is human resources; headmaster and teacher. Then, facilities and the last is teachers' welfare.
\end{abstract}

Keywords: Character, Islamic Boarding School

\section{A. Pendahuluan}

Bangsa Indonesia dewasa ini memerlukan sumber daya manusia yang berkualitas dan berkuantitas, sebagai pendukung utama dalam pembangunan. Untuk memenuhi sumber daya manusia tersebut, pendidikan memiliki peran yang sangat penting. Hal ini sesuai dengan amanat Undang-undang Nomor 20 Tahun 2003 Tentang Sistem Pendidikan Nasional (SISDIKNAS) pada Pasal 3, yang menyebutkan:

"Pendidikan Nasional berfungsi mengembangkan kemampuan dan membentuk karakter serta peradaban bangsa yang bermartabat dalam rangka mencerdaskan kehidupan bangsa. Pendidikan nasional bertujuan untuk berkembangnya potensi peserta didik agar menjadi manusia yang beriman dan bertakwa kepada Tuhan 
Yang Maha Esa, berakhlak mulia, sehat, berilmu, cakap, kreatif, mandiri, dan menjadi warga negara yang demokratis serta bertanggung jawab."

Berdasarkan fungsi dan tujuan pendidikan nasional, jelas bahwa pendidikan di setiap jenjang, mulai dari pendidikan dasar (SD/MI) sampai pendidikan menengah (SMP/MTs dan SMA/MA/SMK) harus diselenggarakan secara sistematis guna mencapai tujuan tersebut. Hal tersebut berkaitan dengan pembentukan karakter peserta didik sehingga mampu bersaing, beretika, bermoral, sopan santun dan berinteraksi dengan masyarakat. Karakter merupakan nilai-nilai perilaku manusia yang berhubungan dengan Tuhan Yang Maha Esa, diri sendiri, sesama manusia, lingkungan, dan kebangsaan yang terwujud dalam pikiran, sikap, perasaan, perkataan, dan perbuatan berdasarkan norma-norma agama, hukum, tata krama, budaya, dan adat istiadat. Dalam buku Desain Induk Pengembangan Karakter, dijelaskan sebagai berikut :

"Pendidikan sebagai suatu upaya sadar mengembangkan potensi peserta didik (siswa), tidak dapat dilepaskan dari lingkungan mereka berada, utamanya lingkungan budaya, karena pendidikan yang tidak dilandasi prinsip budaya menyebabkan peserta didik tercabut dari akar budayanya, dan ketika hal itu terjadi maka mereka tidak akan mengenal budayanya dan akan menjadi asing dalam lingkungan budaya (masyarakat)nya, kondisi demikian menjadikan siswa cepat terpangaruh oleh budaya luar. Kecenderungan itu terjadi karena ia tidak memiliki norma dan nilai budaya yang dapat digunakan untuk melakukan pertimbangan (valueing).,"

Proses pengembangan nilai-nilai yang menjadi landasan dari karakter itu menghendaki suatu proses yang berkelanjutan, dilakukan melalui berbagai mata pelajaran yang ada dalam kurikulum. Dalam mengembangkan pendidikan karakter bangsa, kesadaran akan siapa dirinya dan bangsanya adalah bagian yang teramat penting, kesadaan tersebut hanya dapat terbangun dengan baik melalui pencerahan masa lalu, masa kini dan akan datang tentang bangsanya. ${ }^{3}$ Pendidikan karakter merupakan bagian esensial tugas sekolah dalam hal ini sebagai proses pembudayaan dan pemberdayaan nilai-nilai luhur dalam lingkungan satuan pendidikan (sekolah),

\footnotetext{
${ }^{1}$ Tim Penyusun Diknas RI, Undang-Undang Republik Indonesia Nomor 20 Tahun 2003 Tentang (SISDIKNAS), (Bandung : Penerbit Citra Umbara, 2007), hlm. 3. Ary H.Gunawan, Kebijakan-kebijakan Pendidikan, (Jakarta: Penerbit Rineka Cipta, 2005), hlm. 163.

${ }^{2}$ Tim Penyusun Kemendiknas RI, Desain Induk Pengembangan Karakter, (Jakarta: Dikti 2010), hlm. 5 .

${ }^{3}$ Ibid., hlm. 6.
} 
lingkungan keluarga, dan lingkungan masyarakat. Dalam konteks ini, Zubaedi menyatakan:

"Pendidikan karakter adalah upaya penanaman kecerdasan dalam berfikir, penghayatan dalam bentuk sikap, dan pengamalan dalam bentuk perilaku yang sesuai dengan nilai luhur yang menjadi jati dirinya, diwujudkan dalam interaksi dengan Tuhannya, diri sendiri, antarsesama, dan lingkungannya. Nilai luhur tersebut antara lain kejujuran, kemandirian, sopan santun, kemuliaan sosial, kecerdasan berfikir termasuk kepenasaran akan intelektual, dan berfikir logis. Pendidikan memiliki beberapa tujuan utama yaitu; pengembangkan potensi kalbu/nurani/afektif peserta didik sebagai manusia sekaligus warga bangsa; mengembangkan kebiasaan dan perlaku peserta didik yang terpuji, menanamkan jiwa kepemimpinan dan tanggungjawab, mengembangkan peserta didik menjadi manusia mandiri, kreatif, dan berwawasan kebangsaan, mengembangkan lingkungan belajar yang aman, jujur, penuh kreatifitas dan persahabatan."

Pendidikan karakter bertujuan untuk meningkatkan mutu penyelenggaraan dan hasil pendidikan di sekolah yang mengarah pada pencapaian pembentukan karakter dan akhlak mulia peserta didik secara utuh, terpadu, dan seimbang, sesuai standar kompetensi lulusan. ${ }^{5}$ Pendidikan karakter pada tingkatan institusi mengarah pada pembentukan budaya sekolah, yaitu nilai-nilai yang melandasi perilaku, tradisi, kebiasaan keseharian, dan simbol-simbol yang dipraktikkan oleh semua warga sekolah, dan masyarakat sekitar sekolah. Budaya sekolah merupakan ciri khas, karakter atau watak, dan citra sekolah tersebut di mata masyarakat luas. ${ }^{6}$

Sasaran pendidikan karakter adalah seluruh sekolah di Indonesia negeri maupun swasta daalam berbagai jenjang pendidikan. Semua warga sekolah, meliputi para peserta didik, guru, karyawan administrasi, dan pimpinan sekolah menjadi sasaran program ini. Sekolah-sekolah yang selama ini telah berhasil melaksanakan pendidikan karakter dengan baik dijadikan sebagai best practices, yang menjadi contoh untuk disebarluaskan ke sekolah-sekolah lainnya. Melalui program ini diharapkan lulusan sekolah memiliki keimanan dan ketaqwaan kepada Tuhan Yang Maha Esa, berakhlak mulia, berkarakter mulia, kompetensi akademik yang utuh dan terpadu, sekaligus memiliki kepribadian yang baik sesuai norma-norma dan budaya Indonesia. ${ }^{7}$ Pada tataran yang lebih luas, pendidikan karakter nantinya diharapkan menjadi budaya

${ }^{4}$ Zubaedi, Desain Pendidikan Karakter: Konsepsi dan Aplikasinya Dalam Lembaga Pendidikan, (Jakarta: Kencana Prenada Media Group, 2011), hlm. 11.

5 Ibid., hlm. 12.

${ }^{6}$ Ibid. 
sekolah. Keberhasilan program pendidikan karakter dapat diketahui melalui pencapaian indikator oleh peserta didik sebagaimana tercantum dalam Standar Kompetensi Lulusan SLTP dan SLTA, yang antara lain meliputi sebagai berikut:

1. Mengamalkan ajaran agama yang dianut sesuai dengan tahap perkembangan remaja,

2. Memahami kekurangan dan kelebihan diri sendiri,

3. Menunjukkan sikap percaya diri,

4. Mematuhi aturan-aturan sosial yang berlaku dalam lingkungan yang lebih luas,

5. Menghargai keberagaman agama, budaya, suku, ras, dan golongan sosial ekonomi dalam lingkup nasional,

6. Mencari dan menerapkan informasi dari lingkungan sekitar dan sumber-sumber lain secara logis, kritis, dan kreatif,

7. Menunjukkan kemampuan berpikir logis, kritis, kreatif, dan inovatif,

8. Menunjukkan kemampuan belajar secara mandiri sesuai dengan potensi yang dimilikinya,

9. Menunjukkan kemampuan menganalisis dan memecahkan masalah dalam kehidupan sehari-hari,

10. Mendeskripsikan gejala alam dan social,

11. Memanfaatkan lingkungan secara bertanggung jawab,

12. Menerapkan nilai-nilai kebersamaan dalam kehidupan bermasyarakat, berbangsa, dan bernegara demi terwujudnya persatuan dalam negara kesatuan Republik Indonesia,

13. Menghargai karya seni dan budaya nasional,

14. Menghargai tugas pekerjaan dan memiliki kemampuan untuk berkarya,

15. Menerapkan hidup bersih, sehat, bugar, aman, dan memanfaatkan waktu luang dengan baik,

16. Berkomunikasi dan berinteraksi secara efektif dan santun,

17. Memahami hak dan kewajiban diri dan orang lain dalam pergaulan di masyarakat; Menghargai adanya perbedaan pendapat,

18. Menunjukkan kegemaran membaca dan menulis naskah pendek sederhana;

\footnotetext{
${ }^{7}$ Ibid., hlm. 13.
} 
19. Menunjukkan keterampilan menyimak, berbicara, membaca, dan menulis dalam bahasa Indonesia dan bahasa Inggris sederhana,

20. Menguasai pengetahuan yang diperlukan untuk mengikuti pendidikan menengah,

21. Memiliki jiwa kewirausahaan. ${ }^{8}$

Di Kota Pekanbaru terdapat 14 (empat belas) Pondok Pesantren, yaitu: Pondok Pesantren Babussalam, Pondok Pesantren Darel Hikmah, Pondok Pesantren Nurul Huda, Pondok Pesantren al-Furqan, Pondok Pesantren Umar Ibnu Khattab, Pondok Pesantren al-Ubudiyyah, Pondok Pesantren al-Munawwarah, Pondok Pesantren Modern al-Kautsar, Pondok Pesantren Hidayatullah, Pondok Pesantren Hidayatus Salikin, Pondok Pesantren Teknologi, Pondok Pesantren al-Ikhwan, Pondok Pesantren alMuslimun dan Pondok Pesantren Bahrul Ulum. Masing-masing pondok pesantren tersebut telah menerapkan pendidikan karakter melalui pembiasaan perilaku siswa yang mengarah kepada peningkatan kesadaran diri dan lingkungan, antara lain dengan cara sebagai berikut:

1. Menerapkan metode belajar yang melibatkan partisipasi aktif siswa, yaitu metode yang dapat meningkatkan motivasi siswa karena seluruh dimensi manusia terlibat secara aktif dengan diberikan materi pelajaran yang konkrit, bermakna, serta relevan dalam konteks kehidupannya, (student active learning, contextual learning, inquiry-based learning, integrated learning).

2. Menciptakan lingkungan belajar yang kondusif (conducive learning community) sehingga anak dapat belajar dengan efektif di dalam suasana yang memberikan rasa aman, penghargaan, tanpa ancaman, dan memberikan semangat.

3. Memberikan pendidikan karakter secara eksplisit, sistematis, dan berkesinambungan dengan melibatkan aspek knowing the good, loving the good, and acting the good.

4. Metode pengajaran yang memperhatikan keunikan masing-masing siswa, yaitu menerapkan kurikulum yang melibatkan juga 9 aspek kecerdasan manusia, yaitu : kecerdasan musical, kecerdasan intrapersonal, kecerdasan interpersonal (sosial), kecerdasan visual spasial, kecerdasasan natural (alamiah), kecerdasan

\footnotetext{
${ }^{8}$ Tim Penyusun Kemendiknas RI, op. cit., hlm. 26-27.
} 
Alfiah - Problematika Penerapan Pendidikan Karakter ......

kinestetik tubuh, kecerdasan verbal linguistik dan kecerdasan logika matematika. $^{9}$

Namun demikian, berdasarkan studi pendahuluan, penulis menemukan beberapa kesenjangan yang menjadi indikasi bahwa penerapan pendidikan karakter di Pondok Pesantren yang ada di Kota Pekanbaru tersebut belum memberikan dampak positif terhadap pembentukan karakter siswa (cinta Tuhan dan segenap ciptaan-Nya; kemandirian dan tanggungjawab; kejujuran/amanah, diplomatis; hormat dan santun; dermawan, suka tolong-menolong dan gotong royong/kerja sama; percaya diri dan pekerja keras; kepemimpinan dan keadilan; baik dan rendah hati; karakter toleransi, kedamaian, dan kesatuan). Hal ini antara lain dapat dilihat dari gejala-gejala sebagai berikut:

1. Adanya beberapa kasus kekerasan yang dilakukan oleh siswa/santri, yaitu kasus kekerasan oleh santri pembina terhadap siswa/santri baru pada Masa Orientasi Siswa (MOS), seperti : siswa dipaksa merayap dan berendam di parit dan kolam, mengunya daun-daunan seperti yang terjadi di Pondok Pesantren Darul Hikmah. $^{10}$

2. Masih diberlakukannya penerapan hukuman fisik bagi siswa/santri yang melakukan pelanggaran oleh guru/ustadz pembina, seperti: siswa dibariskan kemudian dipukul dan ditempeleng karena terlambat mengikuti shalat berjama'ah, siswa digunduli kepalanya karena merokok. ${ }^{11}$

3. Berpindahnya beberapa orang siswa/santri dari Pondok Pesantren di Kota Pekanbaru akibat adanya perlakuan yang kurang wajar, baik oleh siswa pembina maupun oleh guru pembina, sebagaimana terjadi pada beberapa orang siswa kelas I Aliyah Pondok Pesantren Darel Hikmah. ${ }^{12}$

Bertitik tolak dari gejala-gejala di atas pada gilirannya mendorong penulis untuk melakukan satu studi berjudul: "Problematika dalam Penerapan Pendidikan Karakter di

${ }^{9}$ Maimunah, Sofyan Sauri dan M. Dahlan, Wawancara, Ponpes Dar al-Hikmah, Ponpes alKautsar dan Ponpes Babussalam, Pekanbaru Januari 2013.

${ }^{10}$ Diakui oleh beberapa orang siswa/santri Pondok Pesantren Darul Hikmah Dhiya Ulfa, Ririn dan Miftahus Sahilah, Siswa, Wawancara, Ponpes Darel Hikmah Pekanbaru, Januari 2013.

${ }^{11}$ Diakui oleh beberapa orang siswa/santri Pondok Pesantren Darul Hikmah Dhiya Ulfa, Ririn dan Miftahus Sahilah, Siswa, Wawancara, Ponpes Darel Hikmah Pekanbaru, Januari 2013. 
Pondok Pesantren Kota Pekanbaru." Melihat kepada permasalahan yang ada, penulis berpendapat bahwa studi ini merupakan kajian yang sangat menarik.

Bertitik tolak dari latar belakang di atas, paling tidak ada tiga permasalahan yang dapat dirumuskan: (1) apa saja problematika dalam penerapan pendidikan karakter di Pondok Pesantren Kota Pekanbaru?; dan (2) apa saja upaya yang dilakukan dalam mengahadapi problematika dalam penerapan pendidikan karakter di Pondok Pesantren Kota Pekanbaru?

Adapun tujuan yang ingin dicapai dan diharapkan dari penelitian ini adalah: (1) untuk mengetahui problematika dalam penerapan pendidikan karakter di Pondok Pesantren Kota Pekanbaru; dan (2) untuk mengetahui upaya yang dilakukan dalam mengahadapi problematika dalam penerapan pendidikan karakter di Pondok Pesantren Kota Pekanbaru.

Adapun kegunaan yang ingin dicapai dan diharapkan dari penelitian ini adalah untuk: (1) memberi masukan bagi praktisi pendidikan tentang upaya yang ditempuh kepala sekolah dalam meningkatkan mutu pendidikan; (2) menjadi dasar bahan kajian bagi penelitian yang terkait pada masa yang akan datang; (3) menambah dan memperkaya kuantitas hasil penelitian keilmuan di bidang pendidikan.

\section{B. Kerangka Teori}

\section{Pengertian Pendidikan Karakter}

Term "Pendidikan" berasal dari kata "didik" dengan awalan "pe" dan akhiran "kan", yang mengandung arti "perbuatan", cara, dan sebagainya. Ia berasal dari bahasa Yunani yaitu "paedagogie", yang berarti bimbingan, yang diberikan kepada anak. Istilah ini kemudian diterjemahkan ke dalam bahasa inggris, "education" yang berarti pengembangan atau bimbingan. ${ }^{13}$ Dalam Islam ada tiga istilah yang dipakai untuk pendidikan yaitu ” 'al-Tarbiyah' (التربية), 'al-Ta'lim'(التعليم) dan 'al-Ta'dib'(التاديب)). Dalam Kamus Bahasa Arab, kata al-Tarbiyah berasal dari tiga kata yaitu; rabba-yarbu (ربا-يربو) yang mengandung arti: bertambah, tumbuh, dan 'rabiya- yarbaa'(ربى-يربى)

\footnotetext{
12 Diakui oleh beberapa orang siswa/santri Pondok Pesantren Darul Hikmah Dhiya Ulfa, Ririn, Miftahus Sahilah dan Adha al-Maududi, Siswa, Wawancara, Ponpes Darel Hikmah dan Ponpes alKautsar Pekanbaru, Januari 2013. 1982), hlm. 459.

${ }^{13}$ Ibrahim Saat, (Ed.), Isu Pendidikan di Malaysia, (Kuala Lumpur: Dewan Bahasa dan Pustaka,
} 
berarti menjadi besar, serta rabba-yarubbu' (رب-يرب) yang berarti memperbaiki, menguasai urusan, menuntun, menjaga, memelihara. ${ }^{14}$ Terminologi Pendidikan antara lain dirumuskan oleh Abu Ahmadi dan Nur Uhbiyati sebagai berikut:

"Pendidikan pada hakikatnya merupakan suatu kegiatan yang secara sadar dan sengaja, serta penuh tanggung jawab yang dilaksanakan oleh orang dewasa kepada anak sehingga timbul interaksi dari keduanya agar anak tersebut mencapai kedewasaan yang dicita-citakan dan berlangsung secara terus menerus."

Menurut Hasbullah, pendidikan adalah usaha orang dewasa dalam pergaulannya dengan anak didik melalui kontak atau komunikasi yang berlangsung secara terus menerus sampai anak didik mencapai kedewasaan."16 Pengertian pendidikan tersebut menunjukkan suatu proses bimbingan, tuntutan, atau pimpinan, yang di dalamnya mengandung unsure-unsur seperti pendidik, anak didik, tujuan dan sebagainya. Berdasarkan Undang-undang Republik Indonesia Nomor 20 Tahun 2003 tentang Sistem Pendidikan Nasional, pasal (1):

"Pendidikan adalah usaha sadar dan terencana untuk mewujudkan suasana belajar dan proses pembelajaran agar peserta didik secara aktif mengembangkan potensi dirinya untuk memiliki kekuatan spiritual keagamaan, pengendalian diri, kepribadian, kecerdasan, akhlak mulia, serta ketrampilan yang diperlukan dirinya, masyarakat, bangsa dan negara."17

Berdasarkan definisi-definisi di atas dapat disimpulkan bahwa pada hakekatnya pendidikan adalah suatu usaha pemberian bantuan dan bimbingan dari orang dewasa yang bertanggungjawab secara sadar dan terencana kepada peserta didik sehingga timbul interaksi antara keduanya yang bertujuan untuk mencapai kedewasaaan dan membentuk kepribadian yang lebih baik secara keseluruhan meliputi jasmani dan rohani sehingga dapat berguna bagi diri sendiri, bagi masyarakat, bangsa dan negara.

Secara harfiah karakter artinya kualitas mental atau kekuatan moral, akhlak atau budi pekerti individu yang menjadi kepribadian khusus, pendorong dan penggerak, serta pembeda satu individu dengan lainnya. ${ }^{18}$ Menurut Raka, Pendidikan Karakter di

\footnotetext{
${ }^{14}$ Karim al-Bastani dkk, al-Munjid fi al-Lughat wa al-'Alam, (Beirut: Dar al-Masyriqi, 1975), hlm. 243-244.

${ }^{15}$ Abu Ahmadi dan Nur Uhbiyati, Ilmu Pendidikan; Suatu Pengantar, (Jakarta: Rinneka Cipta, 2001), hlm. 70.

${ }^{16}$ Hasbullah, Dasar-dasar Ilmu Pendidikan, (Yakarta: Rinneka Cipta, 2005), hlm. 5.

${ }^{17}$ Tim Penyusun Kemendiknas RI, op. cit., hlm. 4. Ari Gunawan, op. cit., hlm. 164.

18 Doni Koesoema, Pendidikan Karakter: Strategi Mendidik Anak di Zaman Global, (Jakarta: Kompas Gramedia, 2011), hlm. 52.
} 
Indonesia pada saat ini diperlukan semua orang, untuk 250 juta rakyat Indonesia. ${ }^{19}$ Oleh Azzet, Pendidikan karakter di Indonesia saat ini adalah kebutuhan yang mendesak, sebab karakter adalah kekuatan yang membentengi diri kita dari segala macam godaan yang mendorong pada tingkah laku tidak terpuji. ${ }^{20}$ Karakter merupakan cara berfikir dan berperilaku yang khas tiap individu untuk hidup dan bekerja sama, baik dalam lingkup keluarga, masyarakat, bangsa, dan negara. ${ }^{21}$

\section{Tujuan, Sasaran dan Nilai-nilai yang Dikembangkan}

Adapun tujuan pendidikan karakter di sekolah dimaksudkan untuk memfasilitasi peserta didik mengembangkan karakter terutama yang tercakup dalam butir-butir Standar Kompetensi Lulusan. (Permen Diknas 23/2006) sehingga mereka menjadi insan yang berkepribadian mulia (cerdas dan kompetitif). Sedangkan sasaran pendidikan karakter di sekolah dimaksudkan untuk memfasilitasi peserta didik mengembangkan karakter terutama yang tercakup dalam butir-butir Standar Kompetensi Lulusan. (Permen Diknas 23/2006) sehingga mereka menjadi insan yang berkepribadian mulia (cerdas dan kompetitif).

Dalam rangkaiannya dengan identitas atau jati diri suatu bangsa, karakter merupakan nilai dasar perilaku yang menjadi acuan tata nilai interaksi antar manusia. Secara universal berbagai karakter dirumuskan sebagai nilai hidup bersama berdasarkan atas pilar; kedamaian (peace), menghargai (respect), kerja sama (cooperation), kebebasan (freedom), kebahagiaan (happiness), kejujuran (honesty), kerendahan hati (humility), kasih sayang (love), tanggung jawab (responssibility), kesederhanaan (simplicity), toleransi (tolerance) dan persatuan (unity). ${ }^{22}$

Karakter religius teraplikasi dalam wujud kehidupan berprilaku yang baik; penuh dengan kebajikan; yakni berprilaku baik terhadap pihak lain (Tuhan Yang Maha Esa, manusia, dan alam semesta) dan terhadap diri sendiri. Dalam dunia modern ini,

\footnotetext{
${ }^{19}$ Gede Raka, dkk., Pendidikan Karakter Di Sekolah: Dari Gagasan Ke Tindakan, (Jakarta: PT. Alex Media Komputindo, Kompas Gramedia, 2011), hlm. 6.

20 Akhmad Muhaimin Azzet, Urgensi Pendidikan Karakter Di Indonesia: Revitalisasi Pendidikan Karakter Terhadap Keberhasilan Belajar dan Kemajuan Bangsa, (Jakarta: Arruz Media, 2011), hlm. 15, Alfred John, Membangun Karakter Tangguh: Mempersiapkan Generasi Anti Kecurangan, Terjemahan oleh Sandiantoro dan Ari Kristanti, (Surabaya : Portico Publishing, 2011), hlm. vii.

${ }^{21}$ Hariyanto Samani, Konsep dan Model Pendidikan Karakter, (Jakarta: PT. Remaja Rosdakarya 2011), hlm. 41

${ }^{22}$ Ibid., hlm. 42.
} 
manusia cenderung melupakan the virtuous life atau kehidupan yang penuh kebajikan, termasuk di dalamnya self-oriented virtuous atau kebajikan terhadap diri sendiri, seperti self control and moderation atau pengendalian diri dan kesabaran; dan other-oriented virtuous atau kebajikan terhadap orang lain, seperti generousity and compassion atau kesediaan berbagi dan merasakan kebaikan. ${ }^{23}$

Karakter moral dalam menurut Dewantara, adalah mendukung perkembangan hidup anak, lahir dan batin dari sifat kodratinya menuju kearah suatu peradaban. ${ }^{24} \mathrm{Di}$ sini jelas pendidikan moral essensinya adalah mengembangkan kecerdasan moral (building moral intelligence) atau mengembangkan kemampuan moral anak, sehingga mampu menentukan benar dan salah, baik dan buruk, yang wajar dan tidak wajar, yang pantas atau tidak pantas, serta yang patut atau tidak patut untuk dikerjakan seseorang.

Karakter kemandirian adalah suatu karakter yang menunjukan adanya rasa percaya diri dan bertanggungjawab dalam menentukan sikap; atau kemampu untuk mengambil keputusan dan menentukan tepat tidaknya tindakan yang diambilnya. Menurut Khan, pendidikan karakter mengajarkan kebiasaan cara berpikir dan perilaku yang membantu individu untuk hidup dan bekerja sebagai keluarga, masyarakat dan bernegara, membantu mereka membuat keputusan dan yang dapat dipertanggungjawabkan. ${ }^{25}$

Karakter nasionalisme (kebangsaan) yaitu suatu bentuk kesadaran akan masyarakat dan bangsanya sendiri. Zubaedi, mengatakan Pendidikan karakter akan memastikan siswa merenungkan etika pribadi mereka dan bagaimana tindakan mereka mempengaruhi orang di sekitar mereka. Pendidikan karakter dapat diartikan sebagai the deliberate us of all dimensions of school life to foster optimal character develompment (usaha kita secara sengaja dari seluruh dimensi kehidupan sekolah untuk membantu pengembangan karakter dengan optimal). ${ }^{26}$ Hal ini berarti bahwa untuk mendukung perkembangan karakter peserta didik harus melibatkan seluruh komponen sekolah baik dari aspek kurikulum (the content of the curriculum), proses pembelajaran ( the procces

\footnotetext{
${ }^{23}$ Tim Penyusun Kemendiknas RI, Desain Induk Pengembangan Karakter, loc. cit.

${ }^{24}$ Ki Hajar Dewantara, Karja Ki Hadjar Dewatara Bagian Pertama: Pendidikan. Yogyakarta: Pertjetakan Taman Siswa 1962), hlm. 484

25 Yahya Khan, Pendidikan Karakter Potensi Diri: Mendongkrak Kualitas Pendidikan, (Yokyakarta: Pelangi Publishing, 2010), hlm. 1.

${ }^{26}$ Zubaedi, op. cit., hlm. 14.
} 
of instruction ), kualitas hubungan ( the quality of relationship), penanganan mata pelajaran ( the handling of discipline ), pelaksanaan aktifitas ko-kurikuler, serta etos seluruh lingkungan sekolah. ${ }^{27}$

\section{Metode, Pendekatan dan Indikator Keberhasilan}

Menurut Koesoema, Pendidikan Karakter merupakan struktur antropologis yang terarah pada proses pengembangan dalam diri manusia secara terus menerus untuk menyempurnakan dirinya sebagai manusia yang mempunyai keutamaan yakni dengan mengaktualisasikan nilai-nilai keutamaan seperti keuletan, tanggung jawab, kemurahan hati, dan semisalnya. ${ }^{28}$ Hal ini karena Koesoema menganggap bahwa jiwa manusia bisa dirubah dengan pendidikan, dan ini bisa dilakukan di sekolah. Di sekolah tersebut bisa diterapkan lima metode pendidikan karakter yakni: (1) mengajarkan pengetahuan tentang nilai, (2) memberikan keteladanan, (3) menentukan prioritas, (4) praksis prioritas dan (5) refleksi. ${ }^{29}$ Semua metode itu dilaksanakan dalam setiap momen di sekolah, kemudian diaktualisasikan di lingkungan masyarakat supaya mereka bisa mengotrolnya dan juga turut serta mempraktekkannya.

Keberhasilan pelaksanaan pendidikan karakter di SLTP dan SLTA dapat dilihat melalui indikator sebagai berikut:

a. Mengamalkan ajaran agama yang dianut sesuai dengan tahap perkembangan remaja,

b. Memahami kekurangan dan kelebihan diri sendiri,

c. Menunjukkan sikap percaya diri,

d. Mematuhi aturan-aturan sosial yang berlaku dalam lingkungan yang lebih luas,

e. Menghargai keberagaman agama, budaya, suku, ras, dan golongan sosial ekonomi dalam lingkup nasional,

f. Mencari dan menerapkan informasi dari lingkungan sekitar dan sumbersumber lain secara logis, kritis, dan kreatif,

g. Menunjukkan kemampuan berpikir logis, kritis, kreatif, dan inovatif,

\footnotetext{
${ }^{27}$ Ibid., hlm. 15.

${ }^{28}$ Ibid., hlm. 58.

${ }^{29}$ Ibid., hlm. 59.
} 
h. Menunjukkan kemampuan belajar secara mandiri sesuai dengan potensi yang dimilikinya,

i. Menunjukkan kemampuan menganalisis dan memecahkan masalah dalam kehidupan sehari-hari,

j. Mendeskripsikan gejala alam dan sosial,

k. Memanfaatkan lingkungan secara bertanggung jawab,

1. Menerapkan nilai-nilai kebersamaan dalam kehidupan bermasyarakat, berbangsa, dan bernegara demi terwujudnya persatuan dalam negara kesatuan Republik Indonesia,

m. Menghargai karya seni dan budaya nasional,

n. Menghargai tugas pekerjaan dan memiliki kemampuan untuk berkarya,

o. Menerapkan hidup bersih, sehat, bugar, aman, dan memanfaatkan waktu luang dengan baik,

p. Berkomunikasi dan berinteraksi secara efektif dan santun,

q. Memahami hak dan kewajiban diri dan orang lain dalam pergaulan di masyarakat; Menghargai adanya perbedaan pendapat,

r. Menunjukkan kegemaran membaca dan menulis naskah pendek sederhana,

s. Menunjukkan keterampilan menyimak, berbicara, membaca, dan menulis dalam bahasa Indonesia dan bahasa Inggris sederhana,

t. Menguasai pengetahuan yang diperlukan untuk mengikuti pendidikan menengah,

u. Memiliki jiwa kewirausahaan. ${ }^{30}$

\section{Sosialisasi, Perencanaan, Pelaksanaan, Kendala dan Evaluasi}

Pelaksanaan pendidikan karakter memerlukan dukungan dari semua warga sekolah, termasuk Komite Sekolah, bahkan orangtua siswa dan masyarakat di sekitar sekolah. Dukungan tersebut akan diperoleh ketika semua warga tersebut memiliki pemahaman yang baik terhadap pentingnya pendidikan karakter dan bagaimana melaksanakannya. Oleh karena itu sebagai langkah awal dari pelaksanaan pendidikan karakter, mutlak dilakukan sosialisasi/pelatihan pendidikan karakter agar semua pihak yang terlibat memperoleh pemahaman yang memadai dalam semua aspek implementasi pendidikan karakter. 
Sosialisasi/pelatihan yang dimaksud idealnya menjangkau semua warga sekolah. Sosialisasi/ pelatihan ini dapat dilaksanakan oleh sekolah sendiri dengan mengundang narasumber yang telah dilatih oleh Kementerian Pendidikan Nasional atau dengan cara mengirimkan warganya mengikuti sosialisasi/ pelatihan yang diselenggarakan oleh pihak lain. Sosialisasi/ pelatihan dianjurkan dilaksanakan dalam format loka karya sehingga peserta tidak hanya terlibat dalam proses memperoleh pengetahuan, tetapi juga keterampilan praktis dan menghasilkan karya/dokumen yang dapat digunakan di sekolah (dengan atau tanpa penyempurnaan lebih lanjut). Setelah warga sekolah memiliki pemahaman yang baik mengenai pendidikan karakter, langkah selanjutnya adalah membuat rencana jangka menengah dan rencana tahunan pelaksanaan pendidikan karakter di sekolah.

Implementasi pendidikan karakter idealnya dimulai secara serentak pada pembelajaran semua mata pelajaran, semua kegiatan pembinaan kesiswaan, dan pengelolaan semua bidang urusan sekolah. Namun demikian disadari bahwa memulai implementasi secara serentak tersebut bukan sesuai yang ringan. Kondisi sumberdaya manusia dan sumberdaya lainnya sangat mempengaruhi kesiapan sekolah mengimplementasikan pendidikan karakter. Oleh karenanya implementasi pendidikan karakter secara terintegrasi dapat dimulai dari beberapa mata pelajaran, sejumlah kegiatan kesiswaan, dan pengelolaan beberapa bidang urusan sekolah. Mata pelajaran, kegiatan pembinaan kesiswaan, dan bidang urusan sekolah yang diberi integrasi pendidikan karakter pada awal implementasi (tahun pertama) dipilih dari yang mudah atau yang siap dan melibatkan paling banyak peserta didik. Implementasi pada tahaptahap (tahun-tahun) selanjutnya diperluas ke pelajaran, kegiatan pembinaan kesiswaan, dan bidang urusan sekolah lainnya sehingga selambat-lambatnya pada tahun ke empat semua telah diberi integrasi pendidikan karakter.

Salah satu prinsip yang diterapkan dalam merancang pelaksanaan pendidikan karakter di sekolah adalah prinsip partisipatif. Semua warga sekolah perlu dilibatkan dalam membuat rancangan. Mereka dilibatkan dalam memutuskan apakah pendidikan karakter serentak dimulai pada semua mata pelajaran, kegiatan pembinaan kesiswaan, dan bidang urusan sekolah ataukah dimulai pada sebagian saja. Bila dimulai pada

${ }^{30}$ Tim Penyusun Kemendiknas RI, op. cit., hlm. 26-27. 
beberapa saja, mereka dilibatkan dalam mengidentifikasi dan menetapkan mata pelajaran, kegiatan pembinaan kesiswaan, dan bidang urusan sekolah yang implementasinya awal. Selanjutnya mereka didengar gagasannya mengenai tahapantahapan implementasi yang layak dan kegiatan-kegiatan dan/atau sumberdaya pendukung apa saja yang perlu ada agar implementasi berjalan dengan baik.

Pada tahap perencanaan telah disusun rencana jangka menengah dan rencana operasional (tahunan) pelaksanaan pendidikan karakter di sekolah. Tahap berikutnya adalah mengimplementasikan rencana operasional dengan mengikuti jadwal sebagaimana tertuang dalam rencana tahunan. Perubahan-perubahan terhadap rencana operasional selama implementasi dapat dilakukan apabila keadaan menghendakinya.

Pelaksanaan pendidikan karakter terintegrasi dalam proses pembelajaran meliputi proses penyusunan silabus, penyusunan RPP, penyiapan bahan ajar dan media, implementasi di kelas, penilaian, monitoring dan evaluasi, dan tindak lanjut. Oleh karena itu yang pertama-tama dilakukan oleh sekolah/guru adalah menyusun/mengadaptasi silabus yang dilanjutkan menyusun/ mengadaptasi RPP, menyusun/ mengadaptasi bahan ajar, dan mengembangkan media pembelajaran yang sesuai.

Pelaksanaan pendidikan karakter baik melalui proses pembelajaran, kegiatan pembinaan kesiswaan, maupun pengelolaan sekolah perlu dimonitor dan dievaluasi setidak-tidaknya setahun sekali. Untuk pelaksanaan monitoring dan evaluasi perlu dibuat panduan singkat yang setidak-tidaknya memuat tujuan, sasaran, komponen/aspek yang domonitor dan dievaluasi, waktu pelaksanaan, pelaksana, instrumen pengumpul data, dan teknis analisis data. Komponen/aspek yang domonitor dan dievaluasi dan instrumen pengumpul data biasanya berbeda-beda antara monitoring dan evaluasi untuk pelaksanaan pendidikan karakter yang terintegrasi dalam pembelajaran, kegiatan kesiswaan, dan manajemen sekolah. Hasil monitoring dan evaluasi dilaporkan dan selanjutnya digunakan untuk merancang pelaksanaan pendidikan karakter pada tahun berikutnya. 


\section{Metode Penelitian}

\section{Jenis Penelitian}

Penelitian ini menggunakan pendekatan kualitatif, dalam pelaksanaan penelitiannya dilakukan secara alamiah, apa adanya, dalam situasi yang normal sesuai dengan keadaan dan kondisinya, menekankan pada deskripsi secara alami. ${ }^{31}$ Dalam penelitian ini, peneliti menggunakan tipe Deskriptif Herminitif. Penelitian deskriptif adalah langkah-langkah melakukan reinterpretasi objek tentang keadaan fenomena sosial yang terdapat pada permasalahan yang diteliti kemudian dihubungkan dengan teori yang ada.

\section{Lokasi Penelitian}

Penelitian ini dilakukan di Pondok Pesantren yang ada di Kota Pekanbaru, yang terdiri dari: Pondok Pesantren Babussalam, Pondok Pesantren Darel Hikmah dan Pesantren Modern al-Kautsar.

\section{Populasi dan Sampel}

Populasi adalah keseluruhan subyek penelitian, sedangkan sampel adalah sebagian atau wakil populasi yang diteliti. ${ }^{32}$ Adapun populasi dalam penelitian ini adalah seluruh Pondok Pesantren yang ada di Kota Pekanbaru. Melihat sifat dan keadaan populasi yang ada, maka penarikan sampel dilakukan dengan menggunakan teknik sampling purposive yaitu teknik penentuan sampel dengan pertimbangan tertentu. Dengan demikian, sampel yang diambil adalah: tiga Pondok Pesantren, yaitu: Pondok Pesantren Darel Hikmah, Pondok Pesantren Babussalam dan Pondok Pesantren Modern al-Kautsar. Penarikan sampel juga dilakukan terhadap santri/siswa, dalam hal ini penulis mengambil sampel hanya Kelas VIII MTs/SMP dan Kelas XI MA/SMA seluruhnya berjumlah 448 orang siswa.

\section{Sumber Data}

Data yang akan dikumpulkan dan diperoleh dalam penelitian ini dapat dikelompokkan kepada:

${ }^{31}$ Suharsimi Arikunto, Prosedur Penelitian Suatu Pendekatan Teori dan Praktek, (Jakarta: Bina Aksara, 2009), hlm. 11.

${ }^{32}$ Ibid., hlm. 138. 
Alfiah - Problematika Penerapan Pendidikan Karakter ......

a. Data Primer: data yang diperoleh langsung dari responden melalui informasi dari hasil wawancara terstruktur tentang problematika dalam penerapan pendidikan karakter di Pondok Pesantren yang ada di Kota Pekanbaru.

b. Data Sekunder: data yang diperoleh melalui dokumentasi atau sumber lainya untuk menunjang objek yang diteliti tentang problematika dalam penerapan pendidikan karakter di Pondok Pesantren yang ada di Kota Pekanbaru.

\section{Teknik Pengumpulan Data}

Data dalam penelitian ini diperoleh dengan teknik pengumpulan data yaitu:

a. Observasi, dilakukan dengan cara mengamati langsung kegiatan pendidikan tentang problematika dalam penerapan pendidikan karakter di Pondok Pesantren yang ada di Kota Pekanbaru,

b. Wawancara, melakukan tanya jawab secara langsung dengan responden untuk memperoleh data tentang problematika dalam penerapan pendidikan karakter di Pondok Pesantren yang ada di Kota Pekanbaru.

c. Studi dokumentasi, dilakukan penulis dengan cara dokumen yang terkait tentang problematika dalam penerapan pendidikan karakter di di Pondok Pesantren yang ada di Kota Pekanbaru.

\section{Tehnik Analisis Data}

Setelah data-data diperoleh, kemudian data dikelompokkan berdasarkan jenis dan sumbernya, penganalisaan data menggunakan metode deskriptif, yaitu menguraikan dengan fakta yang diperoleh kemudian dihubungkan dengan teori yang ada. Data yang diperoleh diukur dengan menggunakan rumus:

$$
\mathrm{P}=\frac{\mathrm{F}}{\mathrm{N}} \times 100 \%
$$

Setelah hasil ditemukan selanjutnya hasilnya dikategorikan dengan kata: baik, cukup baik, kurang baik, dan tidak baik, dan secara kualitatif baik dan tidak penerapan pendidikan karakter di Pondok Pesantren Kota Pekanbaru; Pondok Pesantren Darel Hikmah, Pondok Pesantren Babussalam dan Pondok Pesantren Modern al-Kautsar ditentukan dengan klasifikasi sebagai berikut:

a. $80 \%-100 \%$ (Baik) 

b. $60 \%-79 \%$ (Cukup Baik)
c. $40 \%-59 \%$ (Kurang Baik)
d. $0 \%-39 \%$ (Tidak Baik). ${ }^{33}$

\section{Hasil Penelitian}

1. Problematika Dalam Penerapan Pendidikan Karakter Di Pondok Pesantren Kota Pekanbaru

Dalam penerapan pendidikan karakter Pondok Pesantren Darel Hikmah, Pondok Pesantren Babussalam dan Pondok Pesantren Modern al-Kautsar, telah ditelusuri melalui indikator, yang mencakup: (1) menanamkan disiplin dengan cara datang tepat waktu dan mengecek kediran siswa serta menegur siswa yang terlambat, (2) menanamkan nilai santun, peduli melalui salam dan sapaan ramah (3) menanamkan nilai religius dengan cara berdo'a da hafalan ayat pendek sebelum mulai pelajaran jam pertama serta mendoakan siswa yang tidak hadir karena sakit atau karena halangan lainnya (4) mengaitkan materi/kompetensi yang akan dipelajari dengan karakter dengan merujuk pada silabus, RPP, dan bahan ajar, menyampaikan butir karakter yang hendak dikembangkan selain yang terkait dengan $\mathrm{SK} / \mathrm{KD}$, (5) menanamkan nilai mandiri, berfikir logis, kreatif, kerjasama, dengan cara melibatkan peserta didik mencari informasi yang luas dan dalam tentang topik/tema materi yang dipelajari dengan menerapkan prinsip alam takambang jadi guru dan belajar dari aneka sumber (6) menanamkan nilai kreatif, kerja keras dengan cara menggunakan beragam pendekatan pembelajaran, media pembelajaran, dan sumber belajar lain (7) menanamkan nilai kerjasama, saling menghargai, peduli lingkungan memfasilitasi terjadinya interaksi antarpeserta didik serta antara peserta didik dengan guru, lingkungan, dan sumber belajar lainnya (8) menanamkan nilai rasa percaya diri, mandiri menanamkan nilai kerjasama, saling menghargai, peduli lingkungan dengan cara melibatkan peserta didik secara aktif dalam setiap kegiatan pembelajaran dan memfasilitasi peserta didik melakukan percobaan di laboratorium, studio, atau lapangan menanamkan nilai cinta ilmu, kreatif, logis dengan cara membiasakan peserta didik membaca dan menulis yang beragam melalui tugas-tugas tertentu yang bermakna, (11) menanamkan nilai kreatif, percaya diri, kritis, saling menghargai, santun dengan cara 
memfasilitasi peserta didik melalui pemberian tugas, diskusi, dan lain-lain untuk memunculkan gagasan baru baik secara lisan maupun tertulis dan memberi kesempatan untuk berpikir, menganalisis, menyelesaikan masalah, dan bertindak tanpa rasa takut (12) menanamkan nilai kerjasama, saling menghargai, tanggung jawab dengan cara memfasilitasi peserta didik dalam pembelajaran kooperatif dan kolaboratif dan memfasilitasi peserta didik berkompetisi secara sehat untuk meningkatkan prestasi belajar; memfasilitasi peserta didik membuat laporan eksplorasi yang dilakukan baik lisan maupun tertulis, secara individual maupun kelompok memfasilitasi peserta didik untuk menyajikan hasil kerja individual maupun kelompok; memfasilitasi peserta didik melakukan pameran, turnamen, festival, serta produk yang dihasilkan; memfasilitasi peserta didik melakukan kegiatan yang menumbuhkan kebanggaan dan rasa percaya diri peserta didik; memberikan umpan balik positif dan penguatan dalam bentuk lisan, tulisan, isyarat, maupun hadiah terhadap keberhasilan peserta didik; memberikan konfirmasi terhadap hasil eksplorasi dan elaborasi peserta didik melalui berbagai sumber; memfasilitasi peserta didik melakukan refleksi untuk memperoleh pengalaman belajar yang telah dilakukandan bersama-sama dengan peserta didik dan/atau sendiri membuat rangkuman/simpulan pelajaran. Dengan melihat dan mengkonsultasikan kepada standar prosentase yang ditentukan untuk mengukur diketahui berada pada level baik, ditunjukkan dengan skor: $73,16 \%$.

Tujuan pembangunan karakter yang merupakan upaya perwujudan amanat Pancasila dan Pembukaan UUD 1945 dilatarbelakangi oleh realita permasalahan kebangsaan yang berkembang saat ini, seperti: disorientasi dan belum dihayatinya nilainilai Pancasila, keterbatasan perangkat kebijakan terpadu dalam mewujudkan nilai-nilai Pancasila; bergesernya nilai etika dalam kehidupan berbangsa dan bernegara; memudarnya kesadaran terhadap nilai-nilai budaya bangsa; ancaman disintegrasi bangsa; dan melemahnya kemandirian bangsa. ${ }^{28}$ Untuk mendukung perwujudan citacita pembangunan karakter sebagaimana diamanatkan dalam Pancasila dan Pembukaan UUD 1945 serta mengatasi permasalahan kebangsaan saat ini, maka Pemerintah menjadikan pembangunan karakter sebagai salah satu program prioritas pembangunan nasional. Semangat itu secara implisit ditegaskan dalam Rencana Pembangunan Jangka

\footnotetext{
${ }^{33}$ Suharsimi Arikunto, op. cit., hlm. 34.

${ }^{28}$ Tim Penyusun Kemendikas RI, loc.cit.
} 
Panjang Nasional (RPJPN) tahun 2005-2015, di mana pendidikan karakter ditempatkan sebagai landasan untuk mewujudkan visi pembangunan nasional, yaitu "Mewujudkan masyarakat berakhlak mulia, bermoral, beretika, berbudaya, dan beradab berdasarkan falsafah Pancasila."29 Upaya mewujudkan pendidikan karakter sebagaimana yang diamanatkan dalam RPJPN, sesungguhnya hal yang dimaksud itu sudah tertuang dalam fungsi dan tujuan pendidikan nasional.

Dalam konteks penerapan pendidikan karakter di sekolah, dalam hal ini di Pondok Pesantren Darel Hikmah, Pondok Pesantren Babussalam dan Pondok Pesantren Modern al-Kautsar, maka guru harus memiliki karakter terlebih dahulu. Menurut Hidayatullah, guru berkarakter, bukan hanya mampu mengajar tetapi ia juga mampu mendidik. Ia bukan hanya mampu mentransfer pengetahuan (transfer of knowledge), tetapi ia juga mampu menanamkan nilai-nilai yang diperlukan untuk mengarungi hidupnya. Seorang guru, apalagi guru Pendidikan Agama Islam bukan hanya memiliki kemampuan bersifat intelektual tetapi memiliki kemampuan spiritual sehingga mampu membuka hati peserta didik untuk belajar; yang selanjutnya adalah kemampuan interpersonal sehingga mampu hidup dengan baik di tengah-tengah masyarakat. ${ }^{31}$

\section{Faktor-faktor Pendukung dan Penghambat dalam Penerapan Pendidikan} Karakter Pondok Pesantren Kota Pekanbaru

Adapun faktor-faktor pendukung dan penghambat dalam mengimplementasikan pendidikan karakter di Pondok Pesantren Darel Hikmah, Pondok Pesantren Babussalam dan Pondok Pesantren Modern al-Kautsar, secara rinci dapat dikemukakan sebagai berikut:

\section{Dana}

Dana merupakan faktor utama yang menunjang pelaksanaan pengembangan pendidikan Islam, karena dengan adanya dana sarana dan prasarana yang dibutuhkan dalam pelaksanaan pendidikan dapat diwujudkan, apalagi program pengembangan pendidikan Islam tidak hanya satu macam, Menurut Ustadz Miftah Syarif, Pimpinan Pondok Pesantren Darel Hikmah Pekanbaru dikatakan bahwa dana menjadi salah satu faktor penyebab yang berpengaruh terhadap pelaksanaan pendidikan karakter, karena

\footnotetext{
${ }^{29}$ Ibid., hlm. 7.

${ }^{31}$ Hidayatullah, Pendidikan Karakter: Membangun Peradaban bangsa. (Surakarta: Yuma Pressindo, 2010), hlm. 25.
} 
tanpa dana yang cukup dapat mengakibatkan kurang optimalnya kinerja para pengelola dan guru dalam melaksanakan tugas dan kewajibannya. Sementara itu, di Pondok Pesantren yang dipimpinya tersebut belum ada alokasi dana khusus yang dialokasikan untuk pelaksanaan pendidikan karakter. ${ }^{33}$ Penjelasan yang sama juga disampaikan oleh Ustadz Hanif, Pimpinan Pondok Modern al-Kautsar Kulim Pekanbaru, Ustadz Muhammad Dahlan M. Nur dan Ustadz Isfalal, Tenaga Pengajar Pondok Pesantren Babussalam. ${ }^{34}$ yang pada intinya mereka mengatakan bahwa belum ada dana yang khusus dialokasikan untuk pelaksanaan pendidikan karakter.

\section{Sumber Daya Manusia (Kepala Sekolah dan Guru)}

Dalam penerapan pendidikan karakter di Pondok Pesantren Darel Hikmah, Pondok Pesantren Babussalam dan Pondok Pesantren Modern al-Kautsar, Sumber Daya Manusia, dalam hal ini Kepala Sekolah dan Guru mempunyai peran yang sangat penting. Hal yang menjadi dasar yang dapat mempengaruhi pola perilaku dan bertindak para guru dan siswa. Oleh karena itu Kepala Sekolah dan Guru di Pondok Pesantren Darel Hikmah, Pondok Pesantren Babussalam dan Pondok Pesantren Modern al-Kautsar dituntut untuk dapat mengerti tentang persoalan-persoalan yang timbul demi lancarnya penerapan pendidikan karakter di Pondok Pesantren Darel Hikmah, Pondok Pesantren Babussalam dan Pondok Pesantren Modern al-Kautsar. Menurut Ustadz Miftah Syarif, Pimpinan Pondok Pesantren Darel Hikmah Pekanbaru dikatakan bahwa:

Agar di Pondok Pesantren Darel Hikmah dan Pondok Pesantren lain di Pekanbaru ini benar-benar berhasil sesuai dengan harapan sudah pasti membutuhkan Sumber Daya Manusia (Kepala Sekolah dan Guru) yang benar-benar konsen dalam penerapan pendidikan karakter tersebut dan perlu melibatkan berbagai unsur kependidikan. $^{35}$

Penjelasan yang sama juga disampaikan oleh Ustadz Hanif, Pimpinan Pondok Modern al-Kautsar Kulim Pekanbaru, Ustadz Muhammad Dahlan M. Nur dan Ustadz

\footnotetext{
${ }^{33}$ Miftah Syarif, Pimpinan Pondok Pesantren Darel Hikmah Pekanbaru, Wawancara, Nopember 2013.

${ }^{34}$ Ustadz Hanif, Pimpinan Pondok Modern al-Kautsar Kulim Pekanbaru, Ustadz Muhammad Dahlan M. Nur dan Ustadz Isfalal, Tenaga Pengajar Pondok Pesantren Babussalam, Wawancara, Nopember 2013.

${ }^{35}$ Miftah Syarif, Pimpinan Pondok Pesantren Darel Hikmah Pekanbaru, Wawancara, Nopember 2013.
} 
Isfalal, Tenaga Pengajar Pondok Pesantren Babussalam. ${ }^{36}$ Pembinaan terhadap guru merupakan tanggung jawab penting Kepala Sekolah untuk mencurahkan segala energi dan waktunya dalam meningkatkan prestasi kerja para guru secara maksimal di sekolahnya. Prestasi guru merupakan cermin prestasi kepala sekolah. Upaya yang dilakukan di Pondok Pesantren Darel Hikmah, Pondok Pesantren Babussalam dan Pondok Pesantren Modern al-Kautsar dalam pembinaan guru untuk meningkatkan prestasi kerja antara lain difokuskan pada pembinaan disiplin guru dan pembinaan kemampuan profesional guru. Dalam melakukan pembinaan disiplin guru, kepala sekolah berusaha untuk memberikan pengarahan tentang arti dan pentingnya disiplin guru, menjadi contoh atau teladan dengan menerapkan disiplin pada diri kepala madrasah sendiri, dengan menerapkan disiplin diri diharapkan para guru akan mengikuti sebagaimana disiplin yang diterapkan kepala madrasah dengan penuh kesadaran diri dan tanpa adanya paksanaan.

Selain itu, dalam pembinaan disiplin kepala sekolah juga membentuk tim khusus bidang kedisiplinan guru, tim khusus ini bertugas sebagai pemantau terhadap kedisiplinan guru dalam menjalankan tugasnya. Apabila kedisiplinan guru sudah tercapai maka kelancaran proses pengajaran akan berjalan dengan baik dan lancar juga prestasi kerja yang dihasilkan akan sesuai dengan yang diharapkan. Guru merupakan salah satu faktor yang menentukan keberhasilan program pengajaran dan tujuan madrasah, sehingga para guru dituntut untuk mempunyai kemampuan profesional dalam menjalankan tugasnya dan selalu meningkatkan prestasi kerjanya. Untuk meningkatkan prestasi kerja guru, kepala madrasah harus berupaya untuk mengadakan pembinaan terhadap kemampuan profesional guru.

Adapun upaya yang dilakukan dalam melakukan pembinaan kemampuan profesional guru menurut Ustadz Miftah Syarif, Pimpinan Pondok Pesantren Darel Hikmah Pekanbaru, dengan mewajibkan kepada para guru untuk mengikuti seminarseminar dan pelatihan-pelatihan, dan mengadakan kerja sama dengan sekolah-sekolah lain, mendatangkan para ahli, memberikan kesempatan kepada para guru untuk melanjutkan pendidikannya, menempatkan guru pada proporsi yang sesuai dengan

\footnotetext{
${ }^{36}$ Ustadz Hanif, Pimpinan Pondok Modern al-Kautsar Kulim Pekanbaru, Ustadz Muhammad Dahlan M. Nur dan Ustadz Isfalal, Tenaga Pengajar Pondok Pesantren Babussalam, Wawancara, Nopember 2013.
} 
bidangnya, mengevaluasi kerja guru dan memberi pengarahan-pengarahan, memberikan kesempatan kepada guru untuk saling mengadakan supervisi, menyediakan, mengoptimalkan sarana dan perlengkapan pendidikan. ${ }^{37}$

Penjelasan yang sama juga disampaikan oleh Ustadz Hanif, Pimpinan Pondok Modern al-Kautsar Kulim Pekanbaru, Ustadz Muhammad Dahlan M. Nur dan Ustadz Isfalal, Tenaga Pengajar Pondok Pesantren Babussalam. ${ }^{38}$ Motivasi merupakan faktor pendorong untuk melakukan sesuatu, agar para guru dapat menjalankan dan meningkatkan prestasi kerjanya, maka kepala madrasah harus berupaya memotivasi guru. Upaya yang dilakukan dalam memotivasi guru yaitu menekankan pada motivasi instrinsik dan ekstrinsik dengan cara menciptakan situasi dan kerjasama yang harmonis antar guru, memberikan penghargaan, melibatkan guru dalam setiap kegiatan sekolah, memberi hak kepada guru untuk mengeluarkan pendapat untuk perkembanganperkembangan sekolah, berusaha untuk memenuhi keinginan-keinginan guru dan melengkapi segala kebutuhan yang diperlukan dalam menjalankan tugasnya.

\section{Sarana dan Prasarana}

Kurangnya sarana dan prasarana baik dalam jumlah dan mutu menjadi salah satu faktor pendukung dan penghambat dalam kelancaran penerapan pendidikan karakter di Pondok Pesantren Darel Hikmah, Pondok Pesantren Babussalam dan Pondok Pesantren Modern al-Kautsar Pekanbaru. Menurut Ustadz Miftah Syarif, Pimpinan Pondok Pesantren Darel Hikmah Pekanbaru bahwa sarana dan prasarana yang ada masih sangat terbatas seperti sarana belajar, buku-buku pelajaran dan alat-alat tulis, laboratorium computer dan media pembelajaran. ${ }^{39}$ Penjelasan yang sama juga disampaikan oleh Ustadz Hanif, Pimpinan Pondok Modern al-Kautsar Kulim Pekanbaru, Ustadz Muhammad Dahlan M. Nur dan Ustadz Isfalal, Tenaga Pengajar Pondok Pesantren Babussalam. $^{40}$

\footnotetext{
${ }^{37}$ Miftah Syarif, Pimpinan Pondok Pesantren Darel Hikmah Pekanbaru, Wawancara, Nopember 2013.

${ }^{38}$ Ustadz Hanif, Pimpinan Pondok Modern al-Kautsar Kulim Pekanbaru, Ustadz Muhammad Dahlan M. Nur dan Ustadz Isfalal, Tenaga Pengajar Pondok Pesantren Babussalam, Wawancara, Nopember 2013.

${ }^{39}$ Miftah Syarif, Pimpinan Pondok Pesantren Darel Hikmah Pekanbaru, Wawancara, Nopember 2013.

${ }^{40}$ Ustadz Hanif, Pimpinan Pondok Modern al-Kautsar Kulim Pekanbaru, Ustadz Muhammad Dahlan M. Nur dan Ustadz Isfalal, Tenaga Pengajar Pondok Pesantren Babussalam, Wawancara, Nopember 2013.
} 
Alfiah - Problematika Penerapan Pendidikan Karakter ......

\section{Kesejahteraan Guru}

Disadari sepenuhnya bahwa faktor kesejahteraan guru di Pondok Pesantren Darel Hikmah, Pondok Pesantren Babussalam dan Pondok Pesantren Modern al-Kautsar Pekanbaru ini memang dapat dikatakan masih belum optimal, hal ini disebabkan karena keterbatasan dana dan kemampuan untuk memberikan tunjangan bagi mereka. Imbalan yang diperolehnya menjadi belum seimbang dibandingkan dengan tenaga yang mereka sumbangkan untuk bekerja siang dan malam tanpa mengenal lelah di Pondok Pesantren Darel Hikmah, Pondok Pesantren Babussalam dan Pondok Pesantren Modern al-Kautsar Pekanbaru. Namun pada dasarnya faktor kesejahteraan guru ini jangan sampai menjadi faktor yang menyebabkan lemahnya kinerja.

Menurut Ustadz Miftah Syarif, Pimpinan Pondok Pesantren Darel Hikmah Pekanbaru, bahwa dalam melaksanakan dalam pengembangan pendidikan Islam di Pondok Pesantren Darel Hikmah Pekanbaru dan Pondok Pesantren lainnya tidak terlepas dari semangat dan motivasi dari Kepala Sekolah dan guru dalam melaksanakan tugas dan kewajibannya, di mana tugas dan kewajiban dipengaruhi oleh tingkat kesejahteraan guru. $^{41}$

Penjelasan yang sama juga disampaikan oleh Ustadz Hanif, Pimpinan Pondok Modern al-Kautsar Kulim Pekanbaru, Ustadz Muhammad Dahlan M. Nur dan Ustadz Isfalal, Tenaga Pengajar Pondok Pesantren Babussalam. $^{42}$ Upaya peningkatan kesejahteraan guru yang telah dilakukan sebagaimana disampaikan sebagai berikut:

"Meskipun bentuk kesejahteraan yang saya tekankan lebih pada kesejahteraan mental, akan tetapi saya juga selalu berusaha untuk mengadakan peningkatan kesejahteraan dari segi materi, hal ini bisa dilihat bahwa kalau dahulu gaji yang diberikan kepada guru hanya berupa gaji dari mengajar, akan tetapi pada saat sekarang dengan melihat kebutuhan ekonomi dan harga barang-barang yang semakin meningkat, maka saya berusaha mengusulkan kepada bendahara madrasah untuk memberikan uang transportasi kepada guru dan alhamdulillah disetujui dan uang transportasi tersebut diberikan bersamaan pada saat pemberian gaji guru. Sehingga setiap awal bulan guru menerima gaji yang dihitung dari jumlah jam mengajar ditambah dengan uang transportasi. Alhamdulillah sekarang ini semua guru sudah mendapatkan bantuan dari

\footnotetext{
${ }^{41}$ Miftah Syarif, Pimpinan Pondok Pesantren Darel Hikmah Pekanbaru, Wawancara, Nopember 2013.

${ }^{42}$ Ustadz Hanif, Pimpinan Pondok Modern al-Kautsar Kulim Pekanbaru, Ustadz Muhammad Dahlan M. Nur dan Ustadz Isfalal, Tenaga Pengajar Pondok Pesantren Babussalam, Wawancara, Nopember 2013.
} 
program pemerintah yaitu Insentif dari Kemenag Kota Pekanbaru dan tunjangan Sertifikasi dari Kementrian Agama RI."43

Penjelasan yang sama juga disampaikan oleh Ustadz Hanif, Pimpinan Pondok Modern al-Kautsar Kulim Pekanbaru, Ustadz Muhammad Dahlan M. Nur dan Ustadz Isfalal, Tenaga Pengajar Pondok Pesantren Babussalam. ${ }^{44}$ Kesejahteraan merupakan salah satu faktor penentu produktifitas atau prestasi kerja. Dalam menjalankan tugasnya guru memerlukan kesejahteraan secara psikologis dan materi untuk memenuhi kebutuhan hidupnya. Apabila kesejahteraan guru terpenuhi maka para akan dapat melaksanakan dan meningkatkan kinerjanya dengan baik sesuai dengan fungsi dan tugasnya.

Adapun kiat-kiat yang dilakukan dalam meningkatkan kesejahteraan guru, yaitu berusaha meningkatkan kesejahteraan mental dan materi dengan cara menciptakan iklim madrasah yang aman, damai, menerapkan prinsip kekeluargaan dan komunikasi dengan didasari niat ibadah, pengabdian dan ikhlas, memperlakukan guru sebagai partner dan mengakui keberadaannya dan segala kemampuan yang dimilikinya, memberikan gaji kepada guru pada setiap awal bulan yang terdiri dari gaji mengajar dihitung dari jumlah jam dalam mengajar ditambah uang transportasi.

Dengan Dmikian dapat disimpulkan bahwa faktor-faktor pendukung dan penghambat dalam penerapan pendidikan karakter di Pondok Pesantren Darel Hikmah, Pondok Pesantren Babussalam dan Pondok Pesantren Modern al-Kautsar, mencakup: dana; belum ada dana dana yang khusus dialokasikan untuk pelaksanaan pendidikan karakter, terutama dalam mata pelajaran Pendidikan Agama Islam, sumber daya manusia (kepala sekolah dan guru), sarana dan prasarana dan kesejahteraan guru.

\section{E. Simpulan dan Saran}

\section{Simpulan}

a. Penerapan pendidikan karakter di Pondok Pesantren Kota Pekanbaru; Pondok Pesantren Darel Hikmah, Pondok Pesantren Babussalam dan Pondok Pesantren Modern al-Kautsar telah ditelusuri melalui dua puluh enam

\footnotetext{
${ }^{43}$ Miftah Syarif, Pimpinan Pondok Pesantren Darel Hikmah Pekanbaru, Wawancara, Nopember 2013.
} 
indikator, yang mencakup menanamkan nilai: religus, santun, peduli,menanamkan nilai religius, menanamkan nilai disiplin, rajin, peduli, menanamkan nilai mandiri, berfikir logis, kreatif, kerjasama, kerja keras, menanamkan nilai saling menghargai, peduli lingkungan, menanamkan nilai cinta ilmu, kreatif, logis, menanamkan nilai percaya diri, kritis, menanamkan nilai tanggung jawab, menanamkan nilai jujur, menanamkan nilai memahami kelebihan dan kekurangaN orang lain; tersebut diketahui berada pada level baik, ditunjukkan dengan skor: $73,16 \%$

b. Adapun faktor-faktor pendukung dan penghambat dalam penerapan pendidikan karakter di Pondok Pesantren Darel Hikmah, Pondok Pesantren Babussalam dan Pondok Pesantren Modern al-Kautsar, mencakup : dana; belum ada dana dana yang khusus dialokasikan untuk pelaksanaan pendidikan karakter, terutama dalam mata pelajaran Pendidikan Agama Islam, sumber daya manusia (kepala sekolah dan guru), sarana dan prasarana dan kesejahteraan guru.

\section{Saran}

Dalam konteks penerapan pendidikan karakter di sekolah, dalam hal ini di Pondok Pesantren Darel Hikmah, Pondok Pesantren Babussalam dan Pondok Pesantren Modern al-Kautsar, maka

a. Guru harus memiliki karakter terlebih dahulu guru berkarakter, bukan hanya mampu mengajar tetapi ia juga mampu mendidik,bukan hanya mampu mentransfer pengetahuan (transfer of knowledge), tetapi ia juga mampu menanamkan nilai-nilai yang diperlukan untuk mengarungi hidupnya.

b. Seorang guru bukan hanya memiliki kemampuan bersifat intelektual tetapi memiliki kemampuan spiritual sehingga mampu membuka hati peserta didik untuk belajar; yang selanjutnya adalah kemampuan interpersonal sehingga mampu hidup dengan baik di tengah-tengah masyarakat

${ }^{44}$ Ustadz Hanif, Pimpinan Pondok Modern al-Kautsar Kulim Pekanbaru, Ustadz Muhammad Dahlan M. Nur dan Ustadz Isfalal, Tenaga Pengajar Pondok Pesantren Babussalam, Wawancara, Nopember 2013. 
Alfiah - Problematika Penerapan Pendidikan Karakter ......

\section{F. Daftar Kepustakaan}

Abu Ahmadi dan Nur Uhbiyati, Ilmu Pendidikan: Suatu Pengantar, Jakarta: Rinneka Cipta, 2001.

Abuddin Nata, Filsafat Pendidikan Islam, Jakarta : Logos Wacana Ilmu, 1997.

Ahmad D. Marimba, Pengantar Filsafat Pendidikan Islam, Bandung: Maktabah alMa'rif, 1980.

Akhmad Muhaimin Azzet, Urgensi Pendidikan Karakter Di Indonesia: Revitalisasi Pendidikan Karakter Terhadap Keberhasilan Belajar dan Kemajuan Bangsa, Jakarta: Arruz Media, 2011.

Alfred John, Membangun Karakter Tangguh: Mempersiapkan Generasi Anti Kecurangan, Terjemahan oleh Sandiantoro dan Ari Kristanti, (Surabaya : Portico Publishing, 2011).

Ary H. Gunawan, Kebijakan-kebijakan Pendidikan, Jakarta: Penerbit Rineka Cipta, 2005.

Doni Koesoema, Pendidikan Karakter: Strategi Mendidik Anak di Zaman Global, Jakarta: Kompas Gramedia, 2011.

Gede Raka, dkk., Pendidikan Karakter Di Sekolah: Dari Gagasan Ke Tindakan, Jakarta: PT. Alex Media Komputindo, Kompas Gramedia, 2011.

Hariyanto Samani, Konsep dan Model Pendidikan Karakter, Jakarta: PT. Remaja Rosdakarya 2011.

Hasan Langgulung, Manusia dan Pendidikan: Suatu Analisa Antara Psikologi Dan Pendidikan, Jakarta: Pustaka al-Husna, 1986.

Hasbullah, Dasar-dasar Ilmu Pendidikan, Jakarta: Rinneka Cipta, 2005.

Ibrahim Saat, (Ed.), Isu Pendidikan di Malaysia, Kuala Lumpur : Dewan Bahasa dan Pustaka, 1982.

Karim al-Bastani, et,al., al-Munjid fi al-Lughat wa al-'Alam, Beirut: Dar al-Masyriqi, 1975.

Ki Hajar Dewantara, Karja Ki Hadjar Dewatara Bagian Pertama: Pendidikan. Jogjakarta: Pertjetakan Taman Siswa 1962.

Lexi J. Moleong, Metodologi Penelitian Kualitatif, Bandung: Remaja Rosda Karya, 2000.

Mastuhu, Memberdayakan Sistem Pendidikan Islam, Jakarta: Logos Wacana Ilmu dan Pemikiran, 1999.

Mudyahardjo, Filsafat Ilmu Pendidikan, Bandung: PT. Remaja Rosdakarya, 2001.

Muhaimin dan Abdul Mujib. Pemikiran Pendidikan Islam; Kajian Filosofis dan Kerangka Dasar Operasionalisasinya, Bandung: Tri Genda Karya, 1993.

Muhammad Athiyah al-Abrasyi, Ruh al-Tarbiyah wa al-Ta'lim, Saudi Arabiah: Dar alIhya', tt. 
Omar Mohammad al-Toumy al-Syaibany, Falsafah Pendidikan Islam, Jakarta: Bulan Bintang, 1979.

Solichin Abdul Wahab, Evaluasi Kebijakan Publik, Malang: Penerbit FIA. UNIBRAW dan IKIP Malang, 1997.

Subarsono, Kebijakan Publik, Jakarta: Pustaka Setia, 2003.

Suharsimi Arikunto, Prosedur Penelitian; Suatu Pengantar, Jakarta: Bina Aksara, 2009.

Syafruddin Nurdin dan Basyiruddin Usman, Guru Profesional dan Implementasi Kurikulum, Jakarta: Ciputat Pers, 2004.

Syed Muhammad al-Naquib al-Attas, Konsep Pendidikan Dalam Islam, Terj. Haidar Baqir, Bandung: Mizan, 1994.

Syed Sajjad Husain dan Syed Ali Ashraf, Krisis Pendidikan Islam, Terj. Rahmani Astuti, Bandung: PT. Remaja Rosdakarya, 1986.

Tim Penyusun Diknas RI, Undang-Undang Republik Indonesia Nomor 20 Tahun 2003 Tentang SISDIKNAS, Bandung: Penerbit Citra Umbara, 2007.

Tim Penyusun Kemendiknas RI, Desain Induk Pengembangan Karakter, Jakarta: Dikti, 2010.

Yahya Khan, Pendidikan Karakter Potensi Diri: Mendongkrak Kualitas Pendidikan, Yokyakarta: Pelangi Publishing, 2010.

Zakiah Daradjat, Pendidikan Islam Dalam Keluarga dan Sekolah, Jakarta: Ruhama, 1995.

Pengantar Psikologi Remaja, Jakarta: Bulan Bintang, 1990.

Zubaedi, Desain Pendidikan Karakter: Konsepsi dan Aplikasinya Dalam Lembaga Pendidikan, Jakarta: Kencana Prenada Media Group, 2011. 
